\title{
The social aspects in the identification of children's mental health problems in two health services in Paris, France
}

Nakamura E, Planche $M$, Ehrenberg A. Aspectos sociais na identificação de problemas de saúde mental em crianças em dois serviços de saúde em Paris, França. Interface (Botucatu). 2018; 22(65):411-22.

Children's mental health problems were analyzed from a sociological approach addressing two questions: what are the main children's behaviors identified and considered to be mental health problems, and what are the consequences of this classification for the debate on children's problems in contemporary societies. This quantitative and qualitative study analyzed 275 patients' records from two child mental health services (CMHS) in the northeast area of Paris, France. The majority of children were boys from six to 11 years old; requests were presented mainly by schools and parents; the main problems were behavioural problems, cognitive difficulties and relational problems (boys), and affective or emotional problems (girls). There is an interdependence of a great number of actors who worry about children's behavior and a system of expectations seems to be collectively woven by them as social classifications.

Keywords: Child. Mental health. Children's behavior. Sociological analysis.
Problemas mentais na infância foram analisados da perspectiva sociológica, abordando duas questões: quais os principais comportamentos infantis identificados e considerados problemas de saúde mental, e quais as consequências dessa classificação para o debate dos problemas infantis nas sociedades contemporâneas. Este estudo quanti e qualitativo analisou 275 prontuários de pacientes de dois serviços de saúde mental da infância na região nordeste de Paris, França. A maioria das crianças eram meninos de seis a 11 anos de idade; as queixas foram apresentadas principalmente pelas escolas e pelos pais; os principais problemas eram de comportamento, dificuldades de aprendizagem e de relacionamento (meninos), e problemas afetivos e emocionais (meninas). Há uma interdependência entre um grande número de atores que se preocupam com os comportamentos infantis e um sistema de expectativas parece ser coletivamente tecido por eles como classificações sociais.

Palavras-chave: Criança. Saúde mental. Comportamentos infantis. Análise sociológica.
Eunice Nakamura ${ }^{(a)}$
Maëlle Planche ${ }^{(b)}$
Alain Ehrenberg(c)

\footnotetext{
(a) Laboratório

Interdisciplinar Ciências

Humanas, Sociais

e Saúde (LICHSS),

Departamento de

Políticas Públicas

e Saúde Coletiva, Universidade Federal de São Paulo. R. Silva Jardim, 136, Campus Baixada Santista. Santos, SP, Brasil. 11045-551. eunice_nakamura@ hotmail.com

(b) Institut National de la Santé et de la Recherche Médicale, Centre de recherche médecine, sciences, santé, santé mentale, société (CERMES3), Université Paris Descartes. Paris, França. maelle.planche@ laposte.net

(c) Centre National de la Recherche Scientifique, Institut des Sciences de l'Homme et de la Société, CERMES3, Université Paris Descartes. Paris, França. alain.ehrenberg@ parisdescartes.fr
} 
In the health debate, epidemiological studies developed in the last ten years, mainly in Western countries, indicate a global trend of an increase in mental health problems for children and adolescents. Current estimates indicate that one in four to one in five children and adolescents in the world suffers with some mental disorder ${ }^{1}$. In France, according to the Institut National de la Santé et de la Recherche Médicale (INSERM)², one in eight children suffer from mental health problems. As stated in the INSERM report, French and international studies indicate that $12 \%$ of children and adolescents have one or more mental health problems, the prevalence rates being similar to those observed in other developed countries ${ }^{3}$.

The epidemiological context gives us a quantitative picture of the dimension of childhood mental health problems, but other studies in the field of health and also in social sciences show us the relevance and actuality of the subject, relating childhood mental health problems to: immigration; refugee situations ${ }^{5}$; socioeconomic inequalities and poverty ${ }^{6}$; and familial structure, unemployment and low income ${ }^{7}$. In general these aspects are presented as parts of the social and cultural dimensions of childhood mental health ${ }^{6}$.

The relevance assumed by childhood mental health problems led us to see the need for in depth understanding of the phenomenon, which is analyzed in this paper from a sociological approach addressing two questions: what are the main children's behaviors identified by adults (parents, health professionals, and others) and considered to be childhood mental health problems, and what are the consequences of this classification for the debate on children's problems in contemporary societies. In addition to addressing these questions, childhood mental health problems are analysed referring to two theoretical categories: interdependence ${ }^{8}$ and autonomy ${ }^{8,9}$, also used to explain the place occupied by children in contemporary societies.

\section{Methodology}

This is a quantitative and qualitative study using as its framework documental research of children's personal forms of patients records from two child mental health services (CMHS), located in the northeast area of Paris, France.

We considered the children's personal forms to be documents that include thoughts, meanings, judgements and acts, according to two complementary approaches: as a resource and as a topic. The first approach focuses on what is 'in' the document, revealing the adults' representations of childhood mental health problems related to their descriptions of children's behavior; the second approach emphasizes the impact of the document on schemes of social interactions ${ }^{10}$.

Data were collected from these personal forms, completed the day of the first consultation request by parents or other adults, considered to be important material, as it was not yet 'translated' by health professionals. These forms integrate the patient records of children who received cared in the two CMHSs chosen for a comparative study. In one of these services we analysed one hundred and fiftty personal forms and in the other 125, totalling 275 personal forms analysed. The data were collected in two CMHSs situated in different districts in the same area of the city, enabling us to compare different contexts from two case studies. Then the difference between the services, situated in different districts, the particularities of the population who received care in each of them, and the demands presented by the local actors were considered important aspects for a comparative approach.

The CMHSs are one of the pillars of the French sectorial health system for prevention, evaluation and care provided to childhood mental health problems; bringing together multidisciplinary teams of psychiatrists, psychologists, speech therapists, occupational therapists, psychomotor therapists, nurses and social workers.

Although these services provide care for children and adolescents, for this study we considered only children up to 11 years old at the time their consultation request was made, since this is the age when French children finish elementary school.

The two CMHSs participating in the research study use the same personal information form with the following questions: 
- Responsible for completing the form

- Request number

- Origin of the request

- Parents' and child's family name and given name

- Child's sex, date and place of birth

- Address and telephone number

- Reason(s) for request

- Child's school grade

- Previous healthcare

- Need for interpreter and parents' language

- Consultation proposed (date)

The analysis was centred mainly on the children's profiles (sex and age), the origin of the request (who referred the children to the mental health services) and their reasons for the request (which were the reasons presented by adults and how they were related to children's behaviors that were considered to be problematic). All the forms were read and the information was organized and grouped into broad categories to understand the origin of the request and their reasons. Then these categories were analysed in relation to the children's profiles by using the Modalisa program, which also allowed us to cross-reference the data of the two mental health services.

The confidentiality and anonymity of the mental health services (identified as CMHS 1 and CMHS 2), as well as of the children and their parents, was maintained as ethical aspects to be considered in the project approved by the Ethics Committee.

\section{Results}

\section{The northeast area of Paris}

The CMHS participating in this study are located in two different districts of the northeast area of Paris, considering three main boroughs (18th, 19th and 20th). This is one of the most densely populated areas in Paris and some of its districts are considered priorities because of the great social and urban inequalities and poverty, integrating with urban policies; others are considered to be sensible urban zones and they are integrated with the Urban Renewal Policy.

We have 586,156 inhabitants living in these three boroughs, that is, $26.4 \%$ of the total population of Paris (2.2 million inhabitants) ${ }^{11}$. It is important to note about the population that $17.2 \%$ are foreigners ${ }^{12-14}$.

According to the reports of Paris city hall, in regard to the socio-demographic information of these boroughs some differences must be noted in terms of age: in the 19th borough, $24.9 \%$ of the population is under twenty years old (representing $21.8 \%$ in the 20 th and $19.1 \%$ in the $18^{\text {th }}$ boroughs). On the other hand, $12.4 \%$ of the population in the $20^{\text {th }}$ borough are up to 65 years old (with $11.9 \%$ in the $18^{\text {th }}$ and $11.5 \%$ in the $19^{\text {th }}$ boroughs).

The differences between the boroughs also might be noted in the number of children in the 130,400 families living in the northeast area. The $19^{\text {th }}$ borough is where we find more families with three children (9\%) and with four children or more (5.3\%). In the $18^{\text {th }}$ borough, they represent $6 \%$ and $3.2 \%$ and in the $20^{\text {th }}, 7.1 \%$ and $3.5 \%$, for three and four children families, respectively.

If we consider the population activity in these boroughs, about $98 \%$ of children from six to 14 years old are in school, but only about $70 \%$ of adolescents and young from 15 to 24 year old are in school (with $71.2 \%$ in the $19^{\text {th }}$ borough; $69.8 \%$ in the $20^{\text {th }}$; and only $67.7 \%$ in the $18^{\text {th }}$ ).

The differences we have shown between the boroughs that constitute this area are indicative of social heterogeneity in the population that might be reflected in some way in the manner in which local actors observe and talk about children's behavior and in the problems they identify and present to mental health services, seeking to resolve them. 


\section{Children's profiles}

In the both CMHSs we found a very similar percentage of boys and girls: almost $71 \%$ of children are boys and $28 \%$ are girls (Table 1 ).

The majority of children were concentrated in the 6-11 years of age group (64.7\%); followed by the children who were three to five years old (28.4\%). In France, since 2006, children's education has included primary school, comprising non-compulsory preschool for children who are three to five years old and compulsory elementary school for children from six to 11 years old, the reason why this age group is so important to the analysis.

In both services, it also should be noted that we found almost the same percentage $(6.9 \%)$ of children who were under three years old (7.3\% in CMHS 1 and $6.4 \%$ in CMHS 2), indicating some concerns regarding mental health problems in very young children.

These general data concerning children who received care in the two CMHSs indicated a very similar profile. However, some particularities should be noted. In CMHS 1, 32.7\% of the children were in the group of 3-5 years of age children, while they represented $23.2 \%$ in CMHS 2 . On the other hand, in CMHS 2, children from 6 to 11 years old were $70.4 \%$, while they accounted for $60.0 \%$ of the patient population in CMHS 1.

Table 1. Percentage of children attending the Child Mental Health Services by sex and age.

\begin{tabular}{llccr}
\hline Variable & \multicolumn{1}{c}{ Categories } & CMHS1 & CMHS2 & Total \\
\hline Sex & Boys & 71.3 & 71.2 & 71.3 \\
& Girls & 28.7 & 28.8 & 28.7 \\
Age & 0-2 years old & 7.3 & 6.4 & 6.9 \\
& 3-5 years old & 32.7 & 23.2 & 28.4 \\
& 6-11 years old & 60.0 & 70.4 & 64.7 \\
\hline
\end{tabular}

\section{Categories of the request's origins}

In the forms, we identified eleven different request origins made to the CMHS. However, to facilitate the analysis, we grouped them into seven categories integrated by different actors, as follows:

- Schools: any professional of the school system (principal, teacher, school's doctor, psychologist or nurse), from preschool (3-5 years old) or from elementary school (6-11 years old).

- Parents: requests from one of the children's parents (or guardians).

- Health services: requests presented by a doctor, a healthcare centre, a hospital or other MHS.

- Social services: shelters, social workers or city hall.

- Childhood services: childhood and early childhood services, such as nursery, leisure centers.

- Family or acquaintance: requests from someone close to the parents (family member, friend or acquaintance).

- Others: exceptional demands from funding agencies, criminal or judicial institutions.

In French CMHS, parents are responsible for presenting the request for their children's care. This is the reason why the field "origin of the request" in the forms is in general completed by the parents, but many times, school professionals advise the parents to seek out CMHS care.

In the both services, schools (31.3\%) and parents (31.6\%) were the main actors in presenting the requests for the children's care. However, the role of the health services $(12.4 \%)$, social services $(8.4 \%)$ and childhood services $(7.3 \%$ ) in directing children to both CMHS must also be considered. According to sex, the boys were directed to the both CMHS mainly by schools $(36.7 \%)$, while parents $(45.6 \%)$ were responsible for the girls' requests (Table 2). 
Considering each service, we observed that in the CMHS 1, parents were the main ones responsible for all the requests (32\%); this situation differing from that observed in CMHS 2, where the schools were the main agents responsible for the requests (37.6\%), more than parents $(31.2 \%)$.

Table 2. Percentage of request origins in the Child Mental Health Services by sex.

\begin{tabular}{lrrrrrrrrr}
\hline \multirow{2}{*}{ Request origins } & \multicolumn{3}{c}{ CMHS 1 } & \multicolumn{3}{c}{ CMHS 2 } & \multicolumn{3}{c}{ Total } \\
\cline { 2 - 10 } & Boys & \multicolumn{1}{c}{ Girls } & Total & Boys & Girls & Total & Boys & Girls & Total \\
\hline Schools & 29.9 & 16.3 & 26.0 & 44.9 & 19.4 & 37.6 & 36.7 & 17.7 & 31.3 \\
Parents & 28.0 & 41.9 & 32.0 & 23.6 & 50.0 & 31.2 & 26.0 & 45.6 & 31.6 \\
Health services & 11.2 & 9.3 & 10.7 & 13.5 & 16.7 & 14.4 & 12.2 & 12.7 & 12.4 \\
Social services & 12.1 & 11.6 & 12.0 & 3.4 & 5.6 & 4.0 & 8.2 & 8.9 & 8.4 \\
Childhood services & 8.4 & 4.7 & 7.3 & 9.0 & 2.8 & 7.2 & 8.7 & 3.8 & 7.3 \\
Family or acquaintance & 2.8 & 4.7 & 3.3 & 3.4 & 2.8 & 3.2 & 3.1 & 3.8 & 3.3 \\
Others & 4.7 & 9.3 & 6.0 & 1.1 & - & 0.8 & 3.1 & 5.1 & 3.6 \\
Unanswered & 2.8 & 2.3 & 2.7 & 1.1 & 2.8 & 1.6 & 2.0 & 2.5 & 2.2 \\
\hline
\end{tabular}

Considering the children's ages, we should note in the Table 3 that parents and childhood services were the main agents responsible for the requests (both with $36.8 \%$ ) for those who were up to two years old. The parents were also the source of the majority of requests $(30.8 \%)$ for the children from three to five years old, but in this age group the schools were the second most frequent source of the requests $(24.4 \%)$, followed by childhood services $(12.8 \%)$ and by health and social services, both originating $11.5 \%$ of the requests.

For the children from six to 11 years old, the relevance of the schools in directing the children into care was evident, as they were the main responsible agent for the requests $(37.6 \%)$. It must be noted that the school's requests concerned mainly children from six to 11 years old, those who were in the elementary school. This tendency was also observed in both CMHSs: $32.2 \%$ in CMHS 1 and $43.2 \%$ in CHMS 2.

Nevertheless, a particularity should be noted in CMHS 2, as the requests presented by the schools are also the majority of referrals in the age group 3-5 years old (31\%), more than those referred by parents $(27.6 \%)$. This situation is the inverse from that observed in CMHS 1 where we noted that the parents were the most common origin of the requests presented for children younger than three years old $(36.4 \%)$ and for those aged three to five years old (32.7\%). This confirms a more important role of schools in CMHS 2, as indicated above, with respect to the children in the preschool (3-5 years old) and also in the elementary school (6-11 years old).

Table 3. Percentage of request origins in the Child Mental Health Services by age.

\begin{tabular}{|c|c|c|c|c|c|c|c|c|c|c|c|c|}
\hline \multirow{2}{*}{ Request origins } & \multicolumn{4}{|c|}{ CMHS 1} & \multicolumn{4}{|c|}{ CMHS 2} & \multicolumn{4}{|c|}{ Total } \\
\hline & $0-2$ ys & $3-5$ ys & $6-11$ ys & Total & $0-2$ ys & $3-5$ ys & $6-11$ ys & Total & $0-2$ ys & $3-5$ ys & $6-11$ ys & Total \\
\hline Schools & - & 20.4 & 32.2 & 26.0 & - & 31.0 & 43.2 & 37.6 & - & 24.4 & 37.6 & 31.3 \\
\hline Parents & 36.4 & 32.7 & 31.1 & 32.0 & 37.5 & 27.6 & 31.8 & 31.2 & 36.8 & 30.8 & 31.5 & 31.6 \\
\hline Health services & - & 8.2 & 13.3 & 10.7 & 25.0 & 17.2 & 12.5 & 14.4 & 10.5 & 11.5 & 12.9 & 12.4 \\
\hline Social services & 9.1 & 14.3 & 11.1 & 12.0 & - & 6.9 & 3.4 & 4.0 & 5.3 & 11.5 & 7.3 & 8.4 \\
\hline Childhood services & 36.4 & 12.2 & 1.1 & 7.3 & 37.5 & 13.8 & 2.3 & 7.2 & 36.8 & 12.8 & 1.7 & 7.3 \\
\hline Family or acquaintance & 9.1 & 2.0 & 3.3 & 3.3 & - & - & 4.5 & 3.2 & 5.3 & 1.3 & 3.9 & 3.3 \\
\hline Others & 9.1 & 8.2 & 4.4 & 6.0 & - & - & 1.1 & 0.8 & 5.3 & 5.1 & 2.8 & 3.6 \\
\hline Unanswered & - & 2.0 & 3.3 & 2.7 & - & 3.4 & 1.1 & 1.6 & - & 2.6 & 2.2 & 2.2 \\
\hline
\end{tabular}


The different contexts of the request origins in the CMHSs should indicate the particular regard of the actors for the children in the two districts. Specifically, the place occupied by the social services in CMHS $1(12.0 \%)$ and by the health services in CMHS $2(14.4 \%)$ should be noted, as these data indicate some particularities in the relationships among these actors, differences in the places and roles that they occupy in each district.

\section{Categories of the reasons for requests}

Analysing the request forms, we identified different reasons presented to the CMHS by parents or other adult. To make the comparative analysis, we created and grouped these reasons into nine broad analytical categories identified from the nature of the problems' descriptions, which should be presented as different reasons in one child's request.

- Relational problems: conflict with peers, with parents and relatives, manifestations of aggression or violence toward others, difficulties in relationships. Also considered in this category were all descriptions of children's problems referred to as isolation, inhibitions or reclusiveness, as well as transgression of limits and non-compliance with adult authority.

- Affective or emotional problems: distress, anxiety, stress, hypersensitivity, sadness, crying, diffuse fears (phobias), anger and also self-aggression.

- Cognitive difficulties: children's various learning difficulties, including writing and reading, attention and concentration problems, as well as language difficulties and language delay or expression.

- Behavioral problems: excessive agitation or nervousness.

- School refusal: school absenteeism or refusal of schoolwork.

- Specific problems: mention of problems such as enuresis, encopresis, eating disorders, tics, sleep problems, somatic problems and also psychomotor difficulties.

- Traumatic events: life events such as illness or death, parents' divorce or accident referred to as causes of children's problems.

- Diagnosis: depression, autism, ADHD, among others, usually made by a professional from another health service.

- Evaluation or certificate request: request of a specific health professional evaluation or request of a certificate for social benefits.

With respect to the categories of the request's reasons, we note in the Table 4 that the main problems presented to the services are behavioral problems $(21.8 \%)$ and cognitive difficulties $(19.3 \%)$, followed by affective or emotional problems $(15.6 \%)$. If we considered the children's sex, the main problems for boys were behavior problems $(24.1 \%)$ followed by cognitive difficulties $(21 \%)$, while the girls presented more affective or emotional problems (19.1\%).

When analysing each CMHS separately we could note some particularities. In CMHS 1, the main reasons presented were behavior problems $(25.8 \%)$, mainly in the case of the boys $(28.1 \%)$, and affective or emotional problems $(19.8 \%)$, more frequent for the girls $(22.2 \%)$. Unlike CMHS 1 , in CMHS 2 the main reason presented was cognitive difficulties (20.9\%), mainly in the case of the boys $(23 \%)$, followed by behavioral problems (19\% in the total and $21.5 \%$ for the boys). The girls in this service also presented as the main reason affective or emotional problems $(17.1 \%)$.

In terms of age, Table 5 indicates that the behavior problem is the main request reason especially for the children under two years old $(27.6 \%)$ and for those from three to five years old $(25.2 \%)$. Other reasons presented for the children aged three to five years were cognitive difficulties $(19.7 \%)$. In contrast, for the children who were six to 11 years old, cognitive difficulties were the main reasons presented in the requests $(20.7 \%)$, followed by behavioral problems $(19.7 \%)$ and affective or emotional problems $(15.7 \%)$.

When analysing the reasons of the requests presented to each CMHS separately we found some particularities. In CMHS 1, the main request reasons presented for children from six to 11 years old were behavioral problems $(23.1 \%)$, affective or emotional problems $(20.4 \%)$ and cognitive difficulties $(16.7 \%)$. In CMHS 2, behavioral problems are more frequently mentioned for children from three to five years old $(22.4 \%)$ and cognitive difficulties in the case of those who are six to 11 years old (23\%). 
Table 4. Percentage of the categories of the reasons for requests in the Child Mental Health Services by sex.

\begin{tabular}{lrrrrrrrrr}
\hline \multirow{2}{*}{ Reasons for the requests } & \multicolumn{3}{c}{ CMHS 1 } & \multicolumn{3}{c}{ CMHS 2 } & \multicolumn{3}{c}{ Total } \\
\cline { 2 - 10 } & Boys & Girls & Total & Boys & Girls & Total & Boys & Girls & Total \\
\hline Relational problems & 10.2 & 13.0 & 11.0 & 14.7 & 13.4 & 14.3 & 12.9 & 13.2 & 13.0 \\
Affective or emotional problems & 18.8 & 22.2 & 19.8 & 11.0 & 17.1 & 12.8 & 14.1 & 19.1 & 15.6 \\
Cognitive difficulties & 18.8 & 14.8 & 17.0 & 23.0 & 15.9 & 20.9 & 21.0 & 15.4 & 19.3 \\
Behavioral problems & 28.1 & 20.4 & 25.8 & 21.5 & 13.4 & 19.0 & 24.1 & 16.2 & 21.8 \\
School refusal & 1.6 & 1.9 & 1.6 & 3.1 & 6.1 & 4.0 & 2.5 & 4.4 & 3.1 \\
Specific problems & 9.4 & 11.1 & 9.9 & 14.7 & 17.1 & 15.4 & 12.5 & 14.7 & 13.2 \\
Traumatic events & - & 1.9 & 0.5 & 7.9 & 11.0 & 8.8 & 4.7 & 7.4 & 5.5 \\
Diagnosis & 3.9 & 3.7 & 3.8 & 2.6 & - & 1.8 & 3.1 & 1.5 & 2.6 \\
Evaluation or certificate request & 7.0 & 9.3 & 7.7 & 1.6 & 4.9 & 2.6 & 3.8 & 6.6 & 4.6 \\
Unanswered & 3.1 & 1.9 & 2.7 & - & 1.2 & 0.4 & 1.3 & 1.5 & 1.3 \\
\hline
\end{tabular}

Table 5. Percentage of categories of the reasons for requests $\mathrm{n}$ the Child Mental Health Services by age.

\begin{tabular}{|c|c|c|c|c|c|c|c|c|c|c|c|c|}
\hline \multirow[b]{2}{*}{ Request origins } & \multicolumn{4}{|c|}{ CMHS 1} & \multicolumn{4}{|c|}{ CMHS 2} & \multicolumn{4}{|c|}{ Total } \\
\hline & $\begin{array}{c}0-2 \\
\text { ys }\end{array}$ & $\begin{array}{l}3-5 \\
\text { ys }\end{array}$ & $\begin{array}{c}6-11 \\
\text { ys }\end{array}$ & Total & $\begin{array}{c}0-2 \\
\text { ys }\end{array}$ & $\begin{array}{c}3-5 \\
\text { ys }\end{array}$ & $\begin{array}{c}6-11 \\
\text { ys }\end{array}$ & Total & $\begin{array}{c}0-2 \\
\text { ys }\end{array}$ & $\begin{array}{l}3-5 \\
\text { ys }\end{array}$ & $\begin{array}{c}6-11 \\
\text { ys }\end{array}$ & Total \\
\hline Relational problems & 7.1 & 10.0 & 12.0 & 11.0 & 20.0 & 10.4 & 15.2 & 14.3 & 13.8 & 10.2 & 14.0 & 13.0 \\
\hline Affective or emotional problems & 28.6 & 16.7 & 20.4 & 19.8 & 20.0 & 10.4 & 13.1 & 12.8 & 24.1 & 13.4 & 15.7 & 15.6 \\
\hline Cognitive difficulties & 7.1 & 20.0 & 16.7 & 17.0 & - & 19.4 & 23.0 & 20.9 & 3.4 & 19.7 & 20.7 & 19.3 \\
\hline Behavioral problems & 35.7 & 28.3 & 23.1 & 25.8 & 20.0 & 22.4 & 17.8 & 19.0 & 27.6 & 25.2 & 19.7 & 21.8 \\
\hline School refusal & - & - & 2.8 & 1.6 & - & - & 5.8 & 4.0 & - & - & 4.7 & 3.1 \\
\hline Specific problems & 14.3 & 11.7 & 8.3 & 9.9 & 33.3 & 17.9 & 13.1 & 15.4 & 24.1 & 15.0 & 11.4 & 13.2 \\
\hline Traumatic events & - & - & 0.9 & 0.5 & 6.7 & 9.0 & 8.9 & 8.8 & 3.4 & 4.7 & 6.0 & 5.5 \\
\hline Diagnosis & - & 3.3 & 4.6 & 3.8 & - & 3.0 & 1.6 & 1.8 & - & 3.1 & 2.7 & 2.6 \\
\hline Evaluation or certificate request & 7.1 & 8.3 & 7.4 & 7.7 & - & 6.0 & 1.6 & 2.6 & 3.4 & 7.1 & 3.7 & 4.6 \\
\hline Unanswered & - & 1.7 & 3.7 & 2.7 & - & 1.5 & - & 0.4 & - & 1.6 & 1.3 & 1.3 \\
\hline
\end{tabular}

The data on requests' origins and the reasons for them should complete the scenario for understanding adult's tendencies in identifying and arranging children's behaviors as problems, at the same time that the results bring together the realities of these children.

If we consider that in the both services schools were the main actor in presenting the requests for the children's care $(31.3 \%)$, it should be indicated that the complaints presented by them are especially behavioral problems, cognitive difficulties and relational problems. On the other hand, the main complaints presented by parents are affective and emotional problems, but they also identified behavioral problems, school refusal and traumatic events. It is also necessary to consider the role of childhood services, health and social services in identifying behavioral problems. In general, all these actors are more or less involved in the identification of children's problems; all of them address some aspect of children's behavior.

If the general analysis showed us the context of childhood mental health problems in the northeast area of Paris, by comparing the two CMHS we focused on what is unique for each, the similarities and the differences. There is a need in that context to examine the particular way in which the actors are linked, constituting children's realities, their problems included. 


\section{Discussion}

In recent years, the theme of a parental 'crisis of authority' - often extended to the school - is very much present in the public debate over the explanation for the increase in childhood mental health problems, resulting from the so-called weakening of educational foundations. This has been a recurring topic for decades in France.

This aspect, although recurrent, partially explains what is happening, especially in Western societies. It is necessary to comprehend the psychological changes, by resorting to the analysis of longterm social changes ${ }^{15}$. The evolution of these problems can only be understood from a sociological perspective, by relating childhood mental health problems, as observed in France, to the social changes that have affected the relationships among individuals. From this perspective, we focus on some central questions: 1) the actors responsible for classifying children's behaviors, 2) the principles of the arrangement of childhood mental health problems and 3) some consequences of this process for the current debate on the topic.

The argument based on the 'crisis of authority' to explain the phenomenon is very often confounded with the concept of authoritarianism, revealing a kind of regret concerning the disappearance of a relationship that is " $[\ldots]$ socially normalized between a person who gives orders and the other who obeys"16 (p. 83). Referring to the adult-child relationship, Norbert Elias ${ }^{15}$ shows that we are living in a world in transition, where ancient patterns of authority in this relationship coexist with modern ones, more egalitarian and autonomous. Thus, the problem seems not to be a crisis of a model of authority, but a process of transformation and the possibility to think about adult-child relationships based simultaneously on adult authority and children's autonomy. This transformation implies an arrangement of relationships constituted not only by parents and their children, but also by many other people.

In his study of 'children's civilizing process', Elias ${ }^{15}$ state that this process describes a double movement 'of tightening but also of slackening of constraints'. Enlightened by these ideas on adults' authority crisis, children's autonomy and the interdependence between children and adults, as well as among adults, some aspects emerge from our study in an attempt to answer our central questions, as stated above.

The first aspect leads us to the idea of interdependence that is essential to understand the place of children in society, always in relationship with others, as stated by Elias ${ }^{8}$. The data we presented put in evidence the interdependence of a great number of actors and institutions - parents, teachers, doctors, psychologists - who seem to gravitate around children, worrying about their behavior, their problems, the expression of their subjectivity, believing in the existence of a 'structure of children's personality that would be their own'16 as opposed to that of adults. In doing so, this finding reveals a fundamental concern regarding children and the growing trend to empathy vis-à-vis their specific needs, in our societies ${ }^{16}$. From this perspective, the current scientific precepts - in terms of education, signs of children's well-being or ill-being - seem to play a role in the attention that the various actors pay to children's suffering, with whom they are in everyday relationships. Moreover, the central place now occupied by children cannot be reduced to "[...] an increase of empathy [...]" toward them ${ }^{16}$ (p.82).

The second aspect refers to the reasons adults have for classifying some children's behaviors as problems, which leads us to the nature of the socialization process in contemporary societies. The complexity of this process is related to the requirements and constraints that will be imposed on children to become adults, with a concurrent need for adjustment and prediction of child behavior by adults $^{16}$. By reconstructing the course of the civilizing process in the relationships between parents and children, Elias ${ }^{15}$ compares the treatment reserved for children today with that of the past time, showing a time of transition where socialization models based on authority and autonomy coexisted. Therefore, more than an authority crisis of adults, we can refer to the relative autonomy of children and ask how children's behaviors can be adjusted and predicted by adults in this process, some of them being identified as problems.

It is important to note that currently autonomy has become a collective aspiration. The ways of acting and suffering in society change in an interdependent way, being pervaded with collective 
representations of autonomy. Thus, autonomy pervades all social relationships, that is, "[...] the ideas we have about the relation of interdependence with each other and of independence of each other" 9 (p.6). As a supreme value, autonomy presupposes that individuals are able to make choices, to take initiative, to be agents of their own change.

The meaning of discipline has also changed: it is subordinated to the target of obtaining individual initiative and thus the ability to motivate oneself, tending to self-discipline. If before we had useful individuals because they were docile ${ }^{17}$, currently it is necessary to develop the capacity of individuals to self-activate and control themselves. If we need to discipline, it is not because of obedience, but to develop the skills of empathy and self-reliance.

In this sense, children's behavior problems seem to be classified as problems, less as a resistance to authority or discipline imposed by adults, but more from the need for self-discipline. In modern society, successful education should allow a child to acquire all of these skills. In doing so, adults' interest in certain child behaviors should be understood as a form of regulating them that is a way to help caregivers to develop children into the future agents of their own change ${ }^{9}$.

This leads us to the discussion of the nature of the problems to which people pay attention, as the requests presented to the CMHSs, to be constitutive of the normative expectations of individuals in contemporary societies. The affective dimension (or emotional) is central in our societies; " $[. .$.$] the$ ability to act by oneself without being overwhelmed by one's emotions" appears today as "[...] the condition of successful socialization. The control of inhibition, shame, guilt, anxiety or depression is the major issue of contemporary sociality"18 (p.154). These are 'functional disorders', in the sense that these are both values of civilization and symptoms.

In so doing, the process of children's socialization involves a high degree of control over their impulses and emotions at one level ('tightening'), and a high degree of slackening (negotiations between a child and an adult) at another level ${ }^{16}$. In other words, contemporary socialization involves, on one side, self-expression and its needs; and on the other side, it involves self-control. Both aspects are important to children's development, because their future social inclusion will depend on their ability to cooperate with others. The necessary transformation of children into 'autonomous adults of tomorrow' might also lead to isolation and suffering.

In a society pervaded by the normativity of autonomy, it is not enough only to acquire cognitive skills to ensure proper socialization of children, but also to acquire all procedures of information processing such as perception, reasoning, language, memory or key executive functions ${ }^{19}$.

In this third and final aspect, we wish to return to the idea of interdependence ${ }^{8}$ to focus on a relative weakening of the almost exclusive role of parents in children's education in favor of other institutions and actors. Examining this aspect will allow us to reflect on the 'children's civilizing process' in our contemporary societies. Then, the different contexts of request origins should indicate the particular way the actors look at the children in the two districts where CMHSs are situated, as an important aspect to be considered for the understanding of childhood mental health problems based on certain children's behaviors. This reveals another aspect of our contemporary societies and the evolution of the relationships between adults and children, that Norbert Elias ${ }^{16}$ called "partial parents de-functioning". Because "[...] the more adult society becomes complex and differentiated, the more the transformation of civilizing process of the individual grows and becomes complex"16 (p.99), requiring an investment in the child outside the family, mainly in the historical process started decades ago with the generalization of education. Moreover, if cognitive skills are not enough either, it becomes much more difficult to ask the school alone to ensure the future integration of children, especially of those in the most disadvantaged social environments.

The fact that the parents and the schools are the main agents responsible for directing children to the CMHS could lead us to think on their role in children's socialization. Nevertheless, this role should not be considered determinant in modelling children as objects of adults' views and actions, as we must consider children themselves as parts of this social network that is constituted by adults and children. Besides that, parents and schools are not the only actors to present complaints to the CMHS.

Depending on the sort of complaints and on a child's age and sex, the particular role each actor played is clear in both districts. They constitute the social network responsible for children, 
being interdependent, and at the same time, children are in relation to that network, also as actors. In this sense, the socialization process is based on a dynamic negotiation between adults and children revealing a relationship between children's answers to the adults' world and their need to adapt themselves into a very narrow range of behaviors and possible functions in a society ${ }^{8}$. Such organization around children's problems is socially recognized as just and desirable, not only from the point of view of parents, but also from that of children. It is the child's ability to express, not to obey, which has become the major concern.

\section{Conclusion}

In the current scenario, where children's mental health problems occupy a major place in the scientific and social debate, we sought to understand the phenomenon highlighting the corresponding long-term social changes.

By using the notion of the civilizing process, proposed by Norbert Elias ${ }^{16}$, we intended to highlight the changes in certain social patterns in contemporary societies, which underlie the social model of civilization and guide the relationship between children and adults.

We emphasized two transformations in this understanding, seemingly contradictory, but complementary in social terms: the relative autonomy of children who become adults through the civilizing process; while their interdependence with adults continues to exist.

With respect to autonomy, it is important to mention the moment of transition in which we live today in the relationship between parents and children, moving from representations of authority to a more egalitarian relationship. So, children are encouraged to become adults, with a high degree of self-regulation of their needs required ${ }^{15}$ through social expectations. Thus, children's problems seem to indicate the interaction of a biological maturation process and a social process of civilization, namely, the adjustment in this point in time of social civilization, when " [...] from an uncivilized child an adult more or less civilized is established" 15 [our translation] (p.483). In this sense, children's mental health problems and their expressions through socially elaborated categories seem to express today the social dynamics of the relationship between children and adults, in which the prescriptions based on scientific considerations, especially on psychiatry, start playing a major role.

Therefore, the second aspect of this movement of social transformation in the model of civilization in contemporary societies is evident: interdependence, because the coexistence of individuals puts each person in a complicated and complex network of differentiated chains of interdependence. These are the different social actors who start looking at children and their behaviors, while these actors are responsible for ensuring they have the necessary skills in the learning process: on the one hand, to their adjustment to social norms, and to the need for self-control and self-regulation of their feelings and impulses, on the other.

This question points to a complex negotiation between the actors involved, revealing the interaction or interdependence in society to organize its expectations, especially those related to children.

Thus, if there is a paradox between children's answers to the adult world and some expectations for their behavior, an important aspect to be deepened is at what point, in which contexts and according to which classification the tension between social and individual expectations (children's answers) are solved, either by particular actors or institutions, or directed to the child mental health services. A system of expectations seems to be collectively woven as social classifications by the actors who care about children. 


\section{Acknowledgements}

Part of this work was integrated to the post-doctorate stage of Eunice Nakamura at CERMES 3 in Paris, France, with a Fellowship from the National Council of Technological and Scientific Development (CNPq-Brazil).

\section{Contributors}

Eunice Nakamura: responsible for conceiving, drafting and revising the paper; and for the analysis and interpretation of data. Maëlle Planche: responsible for drafting and revising the paper; and for the analysis and interpretation of data. Alain Ehrenberg: responsible for revising the paper critically; and for the approval of the version to be published.

\section{References}

1. Patel V, Flisher AJ, Hetrick S, McGorry P. Mental health of young people: a global public-health challenge. Lancet. 2007; 369(9569):1302-13.

2. Institut National de la Santé et de la Recherche Médicale (FR). Troubles mentaux: dépistage et prévention chez l'enfant et l'adolescent. Paris: Editions INSERM; 2003 (Dossier de presse).

3. Organisation Mondiale de la Santé (OMS). Santé mentale des enfants et des adolescents [Internet]. Denmark: OMS; 2004 [cited 21 Ago 2010]. Avaiable from: http:// www.afpssu.com/wp-content/uploads/2013/07/oms_sante_mentale.pdf.

4. Kouider EB, Koglin U, Petermann F. Emotional and behavioural problems in migrant children and adolescents in Europe: a systematic review. Eur Child Adolesc Psychiatry. 2013; (23):373-91.

5. Anstiss H, Ziaian T, Procter N, Warland J, Baghrust P. Help-seeking for mental health problems in young refugees: a review of the literature with implications for policy, practice and research. Transcult Psychiatry. 2009; 46(4):584-607.

6. Guzder J, Rousseau C. Editorial: child and community mental health in cultural perspective. Transcult Psychiatry. 2010; 47(5):683-5.

7. Meltzer H, Gatward R, Goodman R, Ford T. The mental health of children and adolescents in Great Britain. London: The Stationery Office; 2000.

8. Elias N. La société des individus. Paris: Fayard; 1991 [1939].

9. Ehrenberg A. Santé mentale: I'autonomie est-elle un malheur collectif?. Esprit. 2014; (402):101-10.

10. Silverman D, editor. Qualitative research. 3rd ed. London: Sage Publications; 2010.

11. Ministère de l'Économie et des Finances (FR). Institut National des Statistiques et des Etudes Economiques (INSEE). Recensement de la population - Populations légales en vigueur à compter du 1er janvier 2017. Paris: INSEE; 2016.

12. Mairie de Paris. Direction du Développement Economique de L'Emploi et de L'Enseignement Supérieur. Structure démographique et socio-économique du $18 \mathrm{e}$ arrondissement. Paris; 2011a. Mission Etudes et Statistiques

13. Mairie de Paris. Direction du Développement Economique de L'Emploi et de L'Enseignement Supérieur. Structure démographique et socio-économique du 19e arrondissement. Paris; 2011b. Mission Etudes et Statistiques

14. Mairie de Paris. Direction du Développement Economique de L'Emploi et de L'Enseignement Supérieur. Structure démographique et socio-économique du 20e arrondissement. Paris; 2011c. Mission Etudes et Statistiques 
15. Elias N. A civilização dos pais. Soc Estado. 2012; 27(3):469-93.

16. Elias N. Au-delà de Freud. Sociologie, Psychologie, Psychanalyse. Paris: Éditions La Découverte; 2010 (Textes à l'appui/ Lab. Sciences Sociales).

17. Foucault M. Surveiller et punir: naissance de la prison. Paris: Gallimard; 1993 [1975].

18. Ehrenberg A. Souffrir au travail: purger les passions ou ouvrir la voie à l'action?. Esprit. 2011; (378):148-57.

19. Heckman JJ. Schools, skills, and synapses [Internet]. Bonn: Institute for the Study of Labor; 2008 [cited 8 Dec 2014]. (IZA Discussion Paper, n. 3515). Avaiable from: http:// ftp.iza.org/dp3515.pdf.

Nakamura E, Planche M, Ehrenberg A. Aspectos sociales en la identificación de problemas de salud mental en niños en dos servicios de salud en París, Francia. Interface (Botucatu). 2018; 22(65):411-22.

Problemas mentales en la infancia se analizaron desde la perspectiva sociológica abordando dos preguntas: cuáles son los principales comportamientos infantiles identificados y considerados problemas de salud mental y cuáles son las consecuencias de esa clasificación para el debate de los problemas infantiles en las sociedades contemporáneas. Este estudio cuanti-cualitativo analizó 275 historiales de pacientes de dos servicios de salud mental de la infancia en la región nordeste de París, Francia. La mayoría de los niños eran del sexo masculino de seis a 11 años; las quejas fueron presentadas principalmente por las escuelas y por los padres; los principales problemas eran de comportamiento, dificultades de aprendizaje y de relaciones (niños) y problemas afectivos y emocionales (niñas). Hay una interdependencia entre un gran número de actores que se preocupan por los comportamientos infantiles y un sistema de expectativas que parece ser tejido colectivamente por ellos como clasificaciones sociales.

Palabras clave: Niños. Salud mental. Comportamientos infantiles. Analisis sociológico.

Submitted in 14/11/16. Approved in 31/01/17. 